in an effort to show that girdle pain is not always characteristic of local lesions of the spinal cord or posterior root ganglia, and that it probably has its origin in some part of the sympathetic system and may sometimes occur in disease of the abdominal viscera, and the frequency with which it occurs at the girdle would suggest investigation of the solar ganglia as playing an important part in its production. I am, Sir, yours faithfully,

Bournemouth, Jan. 5th, $1908 . \quad$ E. CURTIN, M.D. R.U.I.

\section{HYPERTROPHIC STENOSIS OF THE PYLORUS.}

To the Editor of THE LANCET.

SiR,-In THE LanCET of Jan. 11th Dr. W. H. Cooke raises doubts as to the possibility of palpating the enlarged pylorus when it is completely covered by the infantile liver and as to the accuracy of the statement that if lavage fails the only recourse is to try operation. I believe it is possible to feel the enlarged pylorus in nearly every case, sometimes with absolute certainty, at others in such an uncertain way that one can only say it can be felt indefinitely. On the other hand, I am well aware that an enthusiast will feel it, although no enlargement is present. The liver is not a serious drawback, although it may be situated anteriorly to the pylorus. It is generally comparatively easy to press the fingers down and under the liver, even in a well-nourished child. The chief sources of difficulty are a rigidity of the muscles due to crying or straining, a dis. tended abdomen, and a crying child. The question as to the possibility of curing well-marked cases without operation is still sub judice. Undoubtedly some of the milder degrees of the affection may be so cured, but one must bear in mind that the existence of the hypertrophy is often erroneously diagnosed. If I may be allowed to criticise Dr. Oooke's cases on the basis of the few data which he gives in his letter I should suggest that the first case was a typical one of the affection and was incurable by medical treatment, and that the second was probably an instance of pyloric spasm. I cannot believe that it would be impossible to feel a hypertrophied pylorus, if present, in a baby which wasted down to three and a half pounds.

I am, Sir, yours faithfully,

Upper Brook-street, W., Jan, 11th, $1908 . \quad$ EDMUNU CAUTLEY.

\section{To the Editor of THE LANCET.}

SIR,--Your correspondent, Dr. W. H. Cooke, has raised an interesting point with regard to the palpation of the pplorus in this condition. There is no doubt as to the difficulty which is frequently met with in eliciting this sign, but from an impression formed from making post-mortem examinations in ten cases the position of the pylorus in relation to the liver is not, I think, the essential cause of the difficulty. The pylorus after death is usually found at only a slightly higher level than the lower edge of the liver in such a position as would render it fairly easily palpable through the abdominal wall of an emaciated infant as far as this matter is concerned.

It would seem that a more important cause of the obscuring of the pyloric tumour is the relation which it usually bears to the rest of the stomach. In these cases the enlarged stomach tends to become bent upon itself so that the pylorus and the pyloric end of the stomach come to lie behind the rest of the viscus. If the pylorus be sought for by palpation of the abdomen in the region of the right rectus muscle it will be seen that two layers of thickened gastric wall intervene between the hand and the tumour so that the latter cannot be recognised. A more successful method is with the infant lying on his back to place the finger-tips well over into the right flank and to push inwards and slightly upwards below the liver towards the vertebral column.

Further, it is well known that in any one case the pylorus is only intermittently palpable and is most easily found at those times when gastric peristalsis is proceeding. This is usually explained by saying that when the pylorns is spasmodically contracted it becomes harder and so more easily felt. It would seem, however, that this is not the whole truth for the hypertrophied pylorns must be sufficiently firm to be palpable whether in spasm or relaxed. It is, I think, more probable that the explanation lies in the fact that during peristalsis the stomach tends to become straightened out so that the pylorus becomes not only more uncovered but is dragged nearer the surface. In addition, palpation of the pylorus is rendered difficult by the depth and mobility of the tumour, and, one may perhaps add, by the examiner's knowledge that any prolonged attempt to elicit this sign is apt to do harm by causing the child to vomit.

In spite of these difficulties the pylorus usually becomes palpable in such cases as can be watched for a short period, although it is seldom felt at the first examination. In all cases recovering under lavage and dieting the pylorus may be felt from time to time throughout a period extending over many weeks. - I am, Sir, yours faithfully,

REGINALD MIJLER,

Medical Registrar and Pathologist.

Hospital for Sick Children. Great Ormond-street, W.C., Jan. Ilth, 1908.

\section{MIRROR-WRITING.}

Io the Editor of THE LANCET.

SIR,-The case of mirror-writing given by Dr. Vaughan Pendred in THE LANCET of Jan. 4th might perhaps be explained by assuming an abnormal activity of the nervous apparatus concerned in the right hemisphere. A statement as to the existence or not of a tendency to mancinism would have been instructive here. My own case seems worth putting on record, as it involves some points of psychological interest. Being originally "left-handed," when first tanght to write in the usual fashion I was at that time able to write with the untaught left hand the reverse way and with more facility. This habit was early repressed and very soon given up and during seven subsequent years of schooling (ninth to sixteenth year) never indulged, quite unpractised; indeed, almost forgotten. After beginning my medical education it occurred to me that the halting way with which thought followed pen when using the right hand-a fact always the bane of my school examinations, \&c., and which had distressed me-much in view of a far readier faculty of expression in speech-led me to decide on a serious attempt with the left hand as before, "mirror-fashion." The first time I experimented I succeeded, to my surprise, with a rapid, perfectly formed, neat, even elegant, writing, infinitely better than the clumsy right-handed performance. I then found that thought followed pen far more easily, so as to change the writing of consecutive steps of an argument from a misery into a pleasure, though I could not read what I wrote, and had to get help from a looking-glass. In Mark Twain's phrase, "the obstruction was removed." I have continued for ten years using this unsought accomplishment, on transparent paper, and am still unable to read well the reversed words; also there is no doubt that the vocabulary is more limited. But apparently during all those formative years the centres on the right side, though unused, were secretly profiting by the training given to the left. The mancinist no doubt succeeds in developing his right hemisphere by the educational system in many respects, but in writing, and even in reading, those very important factors in culture, he is probably at a grave disadvantage.

I am, Sir, yours faitlufully,

Fomund Hughes, M.R.C.S. Eng., L.R.C.P. Lond.

Liverpool, Jan. 5th, 1908.

\section{THE INFECTIVITY OF CANCER.}

\section{To the Editor of THE LaNCET.}

SIR,-Under the above heading in THE LANCEN of Jan. 11th Dr. A. T. Brand writes: "It was the resemblance between the mitosis of malignant cells and that of normal reproductive tissue cells which led to the enunciation by the director of the Imperial Cancer Research Fund of the famous analogical fallacy that malignant new growths are merely reproductive tissue in abnormal situations." He also writes: "When Farm-r, Moore, and Walker announced their interesting discovery ...... the director of the Imperial Cancer Research Institute hastened to emit the extraordinary declaration, $e x$ cathedra $\hat{a}$, that 'malignant new growths were virtually reproductive tissue arising in abnormal situations.'"

1 have nowhere expressed this opinion as baving been formed by myself and have only mentioned it to combat its tenability. As Dr. Brand has inadvertently misrepresented my attitude by his manner of quoting what Dr. Murray and myself wrote, I ask you to be good enough to print the passage in fall. "From these observations the authors" 